\title{
Correction to: The global technology frontier: productivity growth and the relevance of Kirznerian and Schumpeterian entrepreneurship
}

\author{
Esteban Lafuente • Zoltan J. Acs • Mark Sanders • \\ László Szerb
}

Published online: 11 March 2021

(C) Springer Science+Business Media, LLC, part of Springer Nature 2021

\section{Correction to: Small Bus Econ (2020) 55:153-178 https://doi.org/10.1007/s11187-019- 00140-1}

The article "The global technology frontier: productivity growth and the relevance of Kirznerian and Schumpeterian entrepreneurship", written by Esteban Lafuente, Zoltan J. Acs, Mark Sanders and László Szerb was originally published Online First without Open Access. After publication in volume 55, issue 1, pages $153-$ 178, the author decided to opt for Open Choice and to

The online version of the original article can be found at https://doi.org/10.1007/s11187-019-00140-1

E. Lafuente $(\bowtie)$

Department of Management, Universitat Politècnica de Catalunya, (BarcelonaTech) EPSEB, Av. Gregorio Marañón 44-50, 08028 Barcelona, Spain

e-mail: esteban.lafuente@upc.edu

\section{Z. J. Acs}

Schar School of Policy and Government, George Mason University, 3351 Fairfax Dr.,MS 3B1, Arlington, VA 22201, USA

e-mail: zacs@gmu.edu

M. Sanders

Utrecht University School of Economics, P.O. Box 80125, 3508

TCUtrecht, The Netherlands

e-mail: m.w.j.1.sanders@uu.nl

L. Szerb

Faculty of Business and Economics, University of Pécs, Pécs, Rákóczi 80 7622, Hungary

e-mail: szerb@ktk.pte.hu make the article an Open Access publication. Therefore, the copyright of the article has been changed to (C) The Author(s) 2021 and the article is forthwith distributed under the terms of the Creative Commons Attribution 4.0 International License, which permits use, sharing, adaptation, distribution, and reproduction in any medium or format, as long as you give appropriate credit to the original author(s) and the source, provide a link to the Creative Commons license, and indicate if changes were made. The images or other third party material in this article are included in the article's Creative Commons license, unless indicated otherwise in a credit line to the material. If material is not included in the article's Creative Commons license and your intended use is not permitted by statutory regulation or exceeds the permitted use, you will need to obtain permission directly from the copyright holder. To view a copy of this license, visit http://creativecommons.org/licenses/by/4.0/.

The original article has been corrected.

Publisher's note Springer Nature remains neutral with regard to jurisdictional claims in published maps and institutional affiliations. 